\title{
An encounter with alobar holoprosencephaly: a case report
}

\author{
Prasanna Venugopalan, Fathima Mithilag, Vidhu V. Nair*
}

Department of Obstetrics and Gynecology, Travancore Medical College Hospital, Kollam, Kerala, India

Received: 28 April 2020

Accepted: 30 May 2020

\section{*Correspondence:}

Dr. Vidhu V. Nair,

E-mail: vvnsagitarian@gmail.com

Copyright: (c) the author(s), publisher and licensee Medip Academy. This is an open-access article distributed under the terms of the Creative Commons Attribution Non-Commercial License, which permits unrestricted non-commercial use, distribution, and reproduction in any medium, provided the original work is properly cited.

\begin{abstract}
Alobar holopresencephaly is a rare embryonic condition where there is anomalous fusion of cerebral hemispheres. The key features include neurological impairment and facial dysmorphism like cyclopia, ocular hypertelorism with divided orbits and a proboscis. Obstetric ultrasound and foetal MRI are the diagnostic modalities. Majority of cases are sporadic in origin while a genetic association is also described. A small recurrence risk is noted in cases with sporadic origin. Early diagnosis and pregnancy termination are advisable for the condition since the survival rate is very low.
\end{abstract}

Keywords: Alobar, Cyclopia, Holoprosencephaly, Proboscis, Recurrence, Sporadic, Termination

\section{INTRODUCTION}

Incomplete midline cleavage of prosencephalon between day 18 to day 28 of embryonic gastrulation period result in holoprosencephaly. This lack of cleavage result in partial or complete fusion of frontal lobes with a single ventricle.

Several classification systems have been proposed for the holoprosencephaly, but DeMyer and Zeman in 1963 classified it as alobar, semilobar and lobar types based on the degree of embryonic separation of cerebral hemispheres and the presence or absence of inter hemispheric fissure. ${ }^{1}$ Accordingly, there is a complete lack of cleavage of cerebral cortex, fused thalami, single cerebral ventricle along with absent inter hemispheric fissure and corpus callosum in alobar variety which is the most severe form, moderate fusion with single ventricle and partially fused thalami in semilobar form and in the mildest lobar variety, a part of frontal lobe or ventricular horns are fused.

Apart from these, there is a middle inter hemispheric variant, also known as syntelencephaly, with anomalous midline fusion of posterior frontal and parietal lobes, basal ganglia, thalami and absent body of corpus callosum. $^{2}$

The key features are neurological impairment and facial dysmorphism. Holoprosencephaly sequence is defined as craniofacial abnormalities such as synophthalmia or cyclopia (single eye), ocular hypertelorism, ocular ethmocephaly, microphthalmia or anophthalmia, divided orbits, proboscis above the eye, cebocephaly, single central incisor and median cleft lip or cleft palate. ${ }^{3}$ Hydrocephalus and pituitary dysfunction are a common accompaniment. ${ }^{4}$ Survival rate is very low. Majority of cases are sporadic in origin although genetic aetiology and role of teratogens has also been attributed. Here authors describe a case of a pregnant mother who presented to us as a case of foetal anomaly - alobar holoprosencephaly during her routine fifth month scan.

\section{CASE REPORT}

A 31-year-old pregnant woman, G3P1L1A1, previous caesarean section done seven years back with a healthy child and a spontaneous abortion six years back, presented to us at 19 weeks of gestation. It was a planned pregnancy with regular intake of folic acid, iron and 
calcium. Antenatal visits were regular. She had no known comorbidities, no history of diabetes or epilepsy, no potential teratogenic infections or drug intake, no exposure to radiation or toxic substances and no substance abuse. There was no family history of congenital malformations or genetic syndromes. Her combined nuchal translucency scan with biochemistry screening done at 12 weeks were normal.

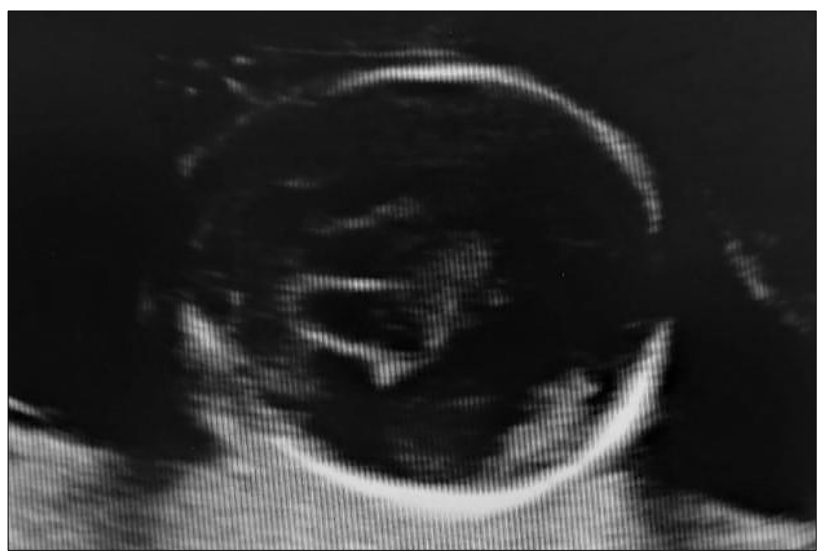

Figure 1: Obstetric 2D ultrasound of mono ventricle a feature of alobar holoprosencephaly.

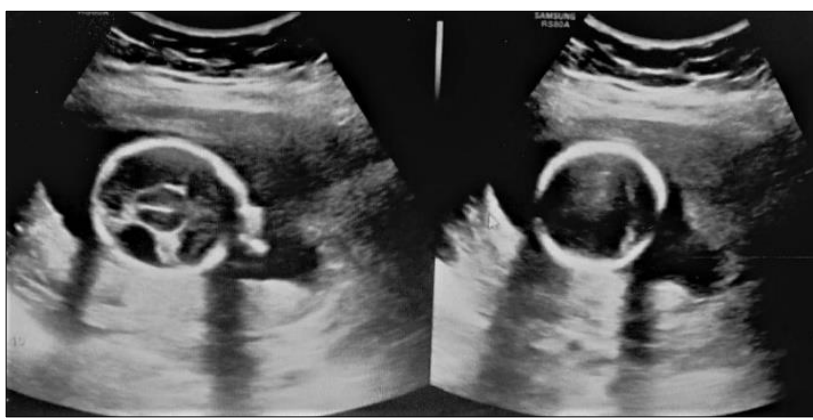

Figure 2: Obstetric 2D ultrasound of fused thalami - a feature of alobar holoprosencephaly.

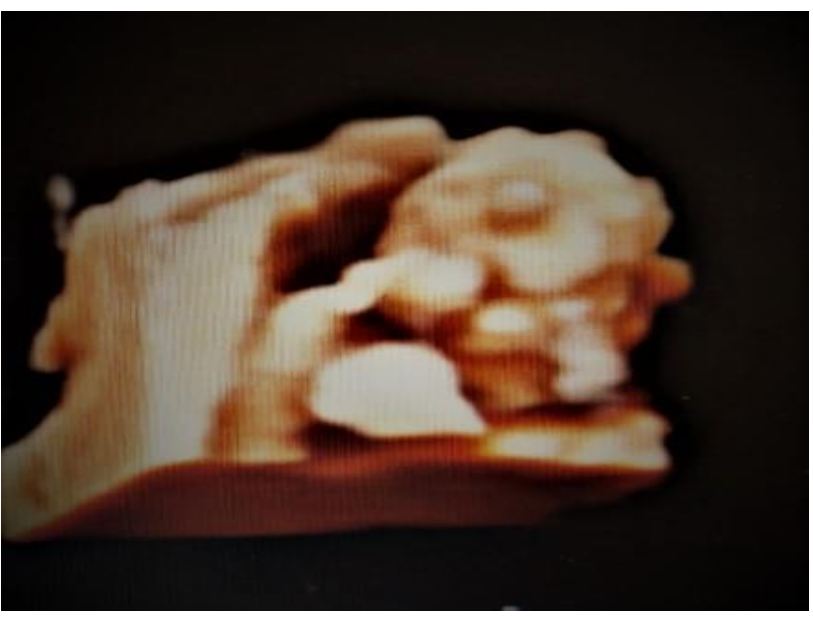

Figure 3: Obstetric 4D ultrasound of anterior proboscis with orbits closely abutting each other - a feature of alobar holoprosencephaly.
At 19 weeks, her anomaly scan showed several abnormalities. The ultrasound findings were large mono ventricle (Figure 1), fused thalami (Figure 2), absent falx, orbits appeared closely abutting each other, midline hypo echoic superficial soft tissue suggestive of an anterior proboscis (Figure 3), four chamber cardiac view showing both right ventricular and left ventricular asymmetry and pulmonary artery appeared reduced in calibre. These findings were confirmed by performing a 4D scan. A diagnosis of foetal anomaly - Alobar holoprosencephaly was made.

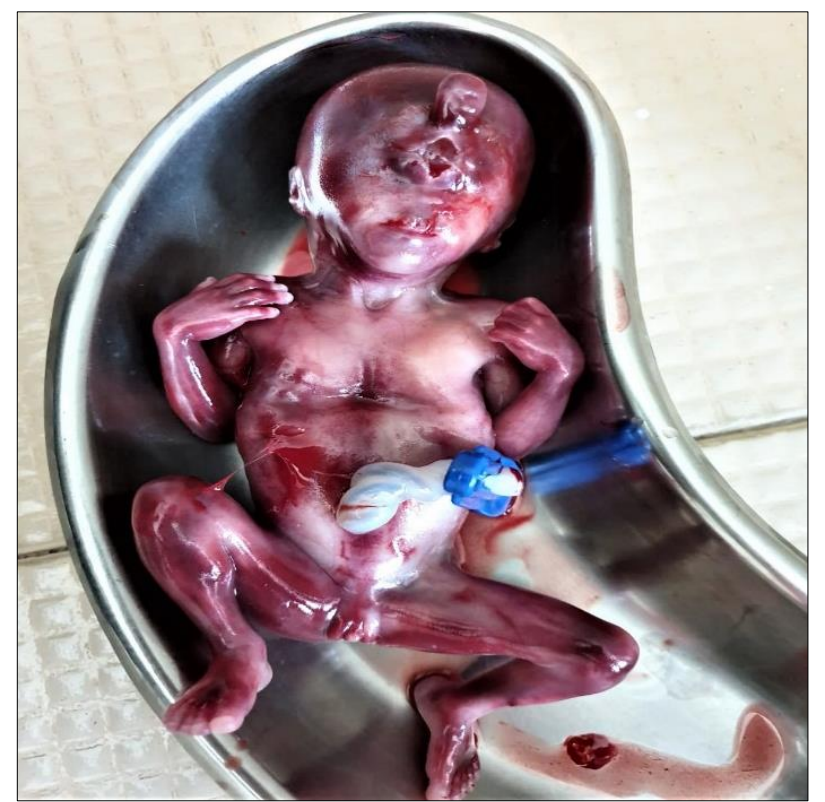

Figure 4: Specimen of a female foetus with fused orbits at the root of nose, cyclopia and proboscis projecting anteriorly above the orbits suggesting alobar holoprosencephaly.

Patient and bystanders were counselled regarding the grave prognosis of the foetal condition and was advised medical termination of pregnancy in view of this anomaly after obtaining consent. Foley's induction was done followed by 2 doses of $400 \mathrm{mcg}$ oral misoprostol tablets. She expelled a female foetus of weight 543 grams. External findings were fused orbits at the root of nose, cyclopia and proboscis projecting anteriorly above the orbits (Figure 4). On foetal autopsy there was single large fused ventricle and thalami with absent falx corroborating with the scan findings.

\section{DISCUSSION}

The incidence of holoprosencephaly is estimated to be 1 in 16,000 live births. ${ }^{5}$ The exact aetiology for the occurrence is unclear but genetic attribution may account for 25 to $45 \% .^{6}$ It has been linked to various monogenic syndromes like Smith-Lemli-Opitz syndrome and Pallister Hall or velo-cardio-facial syndrome. ${ }^{7}$ Mutation of SHH (Sonic Hedge Hog) genes involved in the development of central nervous system mainly cause 
holoprosencephaly, although a total of 14 gene mutations have been implicated. ${ }^{8}$ Foetuses with alobar holoprosencephaly have an association with trisomy 13 , trisomy 18 and triploidies. ${ }^{9}$ The commonly suggested teratogens include alcohol, smoking, antiepileptic's, methotrexate, misoprostol, maternal diabetes, cytomegalovirus infections and other TORCH infections. $^{10}$

Craniofacial anomalies include the severe form of cyclopia or synophthalmia, characterized by single eye at the root of nose, proboscis which is a horn like structure situated above the eye, severe hypertelorism with widely spaced orbits. The survivors of mild lobar varieties commonly encounter pituitary dysfunction, palatal and feeding problems, uncontrollable recurrent seizures, severe developmental delay, hypothalamic and brainstem dysfunction. Pan hypopituitarism may result in short stature, endocrinopathies, electrolyte imbalances and failure to thrive. ${ }^{11}$

Although 2D obstetric ultrasound can diagnose holoprosencephaly, high resolution 4D scan or a foetal MRI helps in detecting other associated craniofacial anomalies and diagnosing lobar, semi lobar and lobar varieties. It also helps in differentiating alobar holoprosencephaly from hydranencephaly by the presence of fused thalami and fused cerebral cortex in the former. ${ }^{12}$ Karyotyping is rarely required since the typical morphological appearance itself speak about the diagnosis.

Management consists of termination of pregnancy on diagnosis. For the survivors of mild lobar type, a lifelong complex treatment is required with hormone replacement therapy, correction of electrolyte and acid base imbalances, permanent gastrostomy tube and surgical repair of facial anomalies. A recurrence risk of $6 \%$ have been described for cases with sporadic origin. ${ }^{13}$

\section{CONCLUSION}

Early diagnosis and termination are a must for this rare anomaly since the chances of long-term survival even with multidisciplinary treatment is very remote.

Funding: No funding sources Conflict of interest: None declared

Ethical approval: Not required

\section{REFERENCES}

1. DeMyer W, Zeman W. Alobar holoprosencephaly (arhinencephaly) with median cleft lip and palate: clinical, electroencephalographic and nosologic considerations (part 1 of 2). Stereot Funct Neurosurg. 1963;23(1):1-6.

2. Dubourg C, Bendavid C, Pasquier L, Henry C, Odent S, David V. Holoprosencephaly. Orphanet J Rare Dis. 2007;2(1):8.

3. Orioli IM, Castilla EE. Epidemiology of holoprosencephaly: prevalence and risk factors. Am J Med Genetics Part C: Seminars in Medical Genetics 2010;154(1):13-21.

4. Hahn JS, Plawner LL. Evaluation and management of children with holoprosencephaly. Pediatric Neurol. 2004;31(2):79-88.

5. Abe Y, Kruszka P, Martinez AF, Roessler E, Shiota $\mathrm{K}$, Yamada S, et al. Clinical and demographic evaluation of a holoprosencephaly cohort from the kyoto collection of human embryos. The Anatomical Record. 2018;301(6):973-86.

6. Nanni L, Schelper RL, Muenke M. Molecular genetics of holoprosencephaly. Pediatr Pathol Mole Medicine. 2000;19(1):1-9.

7. Raam MS, Solomon BD, Muenke M. Holoprosencephaly: a guide to diagnosis and clinical management. Indian Pediatr. 2011;48(6):457.

8. Belloni E, Muenke M, Roessler E, Traverse G, Siegel-Bartelt J, Frumkin A, et al. Identification of Sonic hedgehog as a candidate gene responsible for holoprosencephaly. Nature Genet. 1996;14(3):353.

9. Blaas HG, Eik-Nes SH, Vainio T, Vogt Isaksen C. Alobar holoprosencephaly at 9 weeks gestational age visualized by two-and three-dimensional ultrasound. Ultrasound Obstet Gynecol. 2000;15(1):62-5.

10. Edison RJ, Muenke M. Gestational exposure to lovastatin followed by cardiac malformation misclassified as holoprosencephaly. N Eng J Med. 2005;352(26):2759.

11. DeMyer W, Zeman W, Palmer CG. The face predicts the brain: diagnostic significance of median facial anomalies for holoprosencephaly (arhinencephaly). Pediatr. 1964;34(2):256-63.

12. Yuh WT, Nguyen HD, Fisher DJ, Tali ET, Gao FE, Simonson TM, et al. MR of fetal central nervous system abnormalities. Am J Neuroradiol. 1994;15(3):459-64.

13. Berry SM, Gosden CM, Snijders RJ, Nicolaides KH. Fetal holoprosencephaly: associated malformations and chromosomal defects. Fetal Diagnos Ther. 1990;5(2):92-9.

Cite this article as: Venugopalan P, Mithilag F, Nair VV. An encounter with alobar holoprosencephaly: a case report. Int J Reprod Contracept Obstet Gynecol 2020;9:3069-71. 